\title{
DECISION SUPPORT SYSTEM FOR PROVISION OF NATURAL DISASTER VICTIM LOGISTIC ASSISTANCE WITH TOPSIS METHOD
}

\author{
Enok Tuti Alawiah, Sefrika \\ ${ }^{1}$ Information Systems; ${ }^{2}$ Accounting Information System \\ Faculty of Engineering and Informatics, Bina Sarana Informatics University, Jakarta, Indonesia \\ www.bsi.ac.id \\ 1*enok.etw@bsi.ac.id; 2sefrika.sfe@bsi.ac.id \\ *Corresponding Author
}

\begin{abstract}
At the beginning of 2020 there was a natural disaster that caused many people to lose their homes, damage to public facilities and infrastructure, as well as the breakdown of transportation links connecting villagers, especially in 3 districts namely Sukajaya, Nanggung and Cigudeg. As a result of the disaster, many villages are isolated and residents need a lot of logistical support to meet their needs. To overcome these problems, we need a system that can help the government and volunteers who are interested in the decision making process so that the provision of assistance for victims of natural disasters can be right on target and in accordance with the urgency of basic needs and logistics needed. Decision support systems using the TOPSIS method are used to solve multi-criteria problems by offering various alternative solutions to solve problems. The results obtained a final preference value of 0.68 from C3 criteria in order to prioritize residents with closed transportation access to channel disaster relief funds for victims of natural disasters in Bogor Regency
\end{abstract}

Keywords: Decision support system, TOPSIS, Multikriteria

\begin{abstract}
Abstrak
Awal tahun 2020 terjadi bencana alam yang menyebabkan banyak warga yang kehilangan rumah, rusaknya sarana dan prasarana publik, serta terputusnya jalur transportasi yang menghubungkan warga desa terutama di 3 kecamatan yaitu Sukajaya, Nanggung dan Cigudeg. Akibat dari bencana tersebut, banyak desa terisolir dan warga membutuhkan banyak bantuan logistik untuk memenuhi kebutuhan hidupnya. Untuk mengatasi permasalahan tersebut, diperlukan sebuah sistem yang dapat membantu pemerintah dan relawan yang berkepentingan dalam proses pengambilan keputusan agar pemberian bantuan bagi korban bencana alam dapat tepat sasaran dan sesuai dengan urgensi kebutuhan pokok dan logistik yang diperlukan. Sistem pendukung keputusan dengan metode TOPSIS digunakan untuk menyelesaikan permasalahan multikriteria dengan menawarkan berbagai solusi alternative untuk memecahkan masalah. Hasil penelitian mendapatkan nilai preferensi akhir sebesar 0,68 dari kriteria C3 agar memprioritaskan warga dengan akses transportasi tertutup untuk penyaluran dana bantuan bencana bagi korban bencana alam di Kabupaten Bogor
\end{abstract}

Kata kunci: Sistem pendukung keputusan, TOPSIS, Multikriteria

\section{INTRODUCTION}

Disaster is an event or series of events that threaten and disrupt people's lives. It caused by natural or non-natural factors and themselves. So that many fatalities, environmental damage, property loss, and psychological impact. In Law Number 24 Year 2007 it is defined concerning natural disasters, non-natural disasters, and social disasters. Natural disasters are disasters caused by events or a series of events caused by nature such as earthquakes, tsunamis, volcanic eruptions, floods, droughts, hurricanes, and landslides.

In Bogor Regency there are 22 subdistricts and 250 villages, including disaster prone areas. BPBD (Badan Penanggulangan Bencana Daerah) Bogor Regency noted that there were 35 natural disasters including severe landslides that occurred in Tenjolaya, West Bogor. BNPB noted that 1,092 houses were heavily damaged, 1,625 were moderately damaged, 1,334 were slightly damaged, 10 mosques were heavily damaged, 15 mosques were lightly damaged, 5 schools were 
heavily damaged, 3 schools were moderately damaged, 80 bridges were seriously damaged and 2 bridges were slightly damaged . Natural disasters also claimed the lives of 8 people who died, 3 people were missing, 12 seriously injured and 517 minor injuries (BNPB, 2020).

The impact of this natural disaster, many villages were isolated. The villagers needed many logistics to full fill their daily life. To prevent this problems, it needs a system that can help the government and the volunteer in processing of taking decision so that the logistics distribution will proper in to the target and appropriate with the urgency of their daily needs and their logistics.

The fact is different. When the social assistance distribution system for victims of natural disasters has not been able to run as intended, Various problems related to the victim's daily need is still happens. Mechanisms, procedures and the synergy of potential personnel who have not considered the potential of the region, regional characteristics, disaster characteristics as well as the socio-economic and cultural conditions of the community have become factors that have not yet met the needs of victims in a timely, timely and effective manner (Regence \& Prastyowati, n.d.).

The natural disaster relief distribution system policy is ultimately oriented towards meeting the needs of victims. Fulfillment of the needs of victims of natural disasters will be achieved when there is a match between the operation of the distribution system with regional characteristics, characteristics of disasters, types of disasters, number of victims and losses (Rahayu et al., 2015).

Decision making in an organization is the result of a process of communication and continuous participation of the whole organizationOne of the most fundamental management tasks is to maintain existence and develop the organization. One of the most fundamental management tasks is to maintain existence and develop the organization. Decision making is a very complex. It is because involving people and information. For this reason management must make decisions regarding the steps that must be taken at both the strategy, tactics and operational levels. Decisions to be made to solve problems In order to make better quality decisions, an interactive computer-based system is needed, which can help decision makers utilize data and models to solve unstructured problems.. (Rahayu et al., 2015)

SPK is an interactive information system that provides information, model, and data manipulation. his system is used to assist in decision making in semi structured and unstructured situations (Nursalam, 2016, 2013)

The support system used uses the TOPSIS method, which is one of the multi-criteria decision making methods that was first introduced by Yoon and Hwang in 1981. TOPSIS method is widely used for decision making that has multiple criteria or criteria (Alawiah \& Susilowati, 2018).

Decision Support System for flood disaster logistical assistance that is made on a web-based basis simplify for TRC to transmit disaster data. This can improve time efficiency so that TRC performance becomes more efficient (Nursalam, 2016, 2013).

The decision support system for reconstruction funds for victims of natural disasters is implemented using the Borland Delphi 7 programming language, using a MySQL database and reports are created using Quick Report. The system is used to determine the recipient of funds in according with the availability of funds that involve various factors that are used as criteria as the main factor for obtaining the reconstruction funds, namely the condition of the family is a supporting factor. The results of this system will give an alternative assessment for decision makers to determine who will receive reconstruction funds (Rahayu et al., 2015).

The house has important function for individuals and families. It is not only includes physical aspects, but also mental and social. To support the function of the house as a good place to live, so physical conditions must be fulfilled physical requirements, namely safe as a shelter, mentally fulfills a sense of comfort and can socially protect the privacy of every family member, the house is also become a media for the implementation of family guidance and education. With the fulfillment of one of the basic needs in the form of a decent house, it is expected to achieve family resilience. Implementation of poor housing reconstruction program carried out by the Social Service through Bapernas ((Badan Pemberdayaan Masyarakat)) which began with data collection on prospective recipients of reconstruction assistance for poor houses that were known and recommended by the head of district and the village chief. Based on the collective data, The Social office ranks and makes decisions about prospective recipients of reconstruction assistance for poor houses based on the criteria of poor families determined by the Social Service (Parjono et al., 2015).

The research was conducted using the TOPSIS method (Technique for Order Preference by Similarity to Ideal Solution). The TOPSIS method is used because this method can solve 
multi criteria problems by offering various alternative solutions to solve the problem. The results obtained a preference value of 0.58 from the $\mathrm{C} 2$ criterion of owning a house using their own name. Therefore, a decision system that can be implemented to provide assistance to the RS_RUTILAHU program can consider aspects of home ownership on its own behalf (Alawiah \& Putri, 2019).

Decision support system is a method used to solve problems accurately, quickly, effectively and efficiently. Decision Support System is made with the aim to help the decision making process by choosing the various alternative decisions. Technique for Order Preference by Similarity to Ideal Solution (TOPSIS) is a multi-criteria decision making method based on a concept. the concept is that the best alternative not only has the shortest distance from the positive ideal solution but also has the longest distance from the negative ideal solution. This concept is widely used to solve practical decision problems.

The aim of this research is to help governments and volunteers who wants to help disaster victims be able to distribute the donation to the target by using the proper decision support system. This study aims to help governments and volunteers who want to help disaster victims be able to channel aid funds on target by using the right decision support system.

\section{RESEARCH METHODS}

the research materials used are;

\section{Data Sources}

He research data is from the National Disaster Management Agency (BNPB) of Bogor Regency

\section{Research Population}

Population of this research is in 3 districts of Bogor regency. The details are:

Table 1 Total Study Population

\begin{tabular}{lll} 
& \multicolumn{2}{c}{ Table 1 Total Study } \\
\hline No & Target Criteria & Total \\
\hline 1 & Sukajaya & 14.730 \\
2 & Nanggung & 5.310 \\
3 & Cigudeg & 1.702 \\
\hline Total & & 21.742 \\
\hline
\end{tabular}

\section{Samples and Sample Selection Methods}

Samples were taken from the population, namely victims of disasters in the Districts of Sukajaya, Nanggung, and Cigudeg. Minimum sampling according to Hair in (Alawiah \& Susilowati, 2018) Maximum Likelihood estimation technique is used because it is more efficient and is used on samples of 100 to 200. Samples can also use census methods in this case almost all craftsmen can be used as research samples.

\section{Research Instruments}

The questionnaire used in this study was the closed question with a limited number of statements and answers in advance. The questions on the questionnaire were closed based on studies from various sources related to research. The questions used in the questionnaire were measured using five Likert scales (Table 2) adapted from with the provisions of the answers and values as follows.

Table 2 Likert Scale

\begin{tabular}{lcc}
\hline \multirow{2}{*}{ Answer } & \multicolumn{2}{c}{ score } \\
\cline { 2 - 3 } & Positif & Negatif \\
\hline Always & 5 & 1 \\
\hline Often & 4 & 2 \\
\hline Sometimes & 3 & 3 \\
\hline Almost Never & 2 & 4 \\
\hline Never & 1 & 5 \\
\hline Sour
\end{tabular}

Source:(Sugiyono, 2017)

\section{Research Methods}

The research method uses TOPSIS, the research is divided into several stages, namely:

\section{a. Normalized Decision Matrix Analysis}

Making a normalized decision matrix is a stage in the TOPSIS method that requires a performance rating of each alternative $\mathrm{Ai}$ on each normalized $\mathrm{Ci}$ criterion.

$\mathrm{rij}=\frac{\mathrm{Xij}}{\sqrt{\sum_{i=1}^{m} X_{i f}^{z}}}$

Under the condition:

$\mathrm{i}=1,2 \ldots \mathrm{m}$

$\mathrm{j}=1.2 \ldots . \mathrm{n}$

rij = normalized decision matrix

$\mathrm{Xij}=$ the weight of the criteria to $\mathrm{j}$ in alternative $-\mathrm{i}$

$\mathrm{I}=$ alternative to $\mathrm{i}$

$\mathrm{J}=$ alternative to $\mathrm{j}$

\section{b. Normalized Matrix (R)}

Calculate the normalized matrix (R) with the following formula:

$\mathrm{rij}=\frac{\mathrm{xij}}{\sqrt{\sum_{\mathrm{i}=1}^{\mathrm{m}} \mathrm{x}_{\mathrm{if}}^{2}}}$

where $: i=1,2 \ldots . ., \mathrm{m}$; and $\mathrm{j}=1,2, \ldots . ., \mathrm{n}$ 


\section{c. Weighted Normalized Matrix (Y)}

Calculate a weighted normalized matrix

(Y) with the following formula:

$\mathrm{W}=\{\mathrm{W} 1, \mathrm{~W} 2, \mathrm{~W} 3, \mathrm{~W} 4, \ldots \mathrm{Wn}\}$

$\mathrm{Yif}=\mathrm{Wi}$ Rij

Where $i=1,2, \ldots, m$; and $j=1,2, \ldots, n$

d. Positive ideal solution matrix $(A+)$ and negative ideal solution matrix (A-)

Calculate positive $(\mathrm{A}+)$ and negative $(\mathrm{A}-)$ ideal solutions with the following formula:

$\mathrm{A}^{+}=\left(Y_{1}^{+}, Y_{2}^{+}, \ldots \ldots, Y_{n}^{+}\right.$

$\mathrm{A}^{-}=\left(Y_{1}^{-}, Y_{2}^{-}, \ldots ., Y_{n}^{-}\right.$

Where:

$Y_{j}^{+}$is :

- $\quad \operatorname{Max} Y_{i j}$, if $j$ is an attribute of benefit

- $\quad \operatorname{Min} Y_{i j}$, if $j$ is an attribute of cost

- $\boldsymbol{Y}_{\boldsymbol{j}}^{-}$is :

- $\quad$ Min $Y_{i j}$ if $j$ is an attribute of benefit

- $\operatorname{Max} Y_{i j}$, if $j$ is an attribute of cost

e. Distance of Ideal Negative Solution (D-) and Positive Ideal Solution (D +)

Calculate the distance of a negative ideal solution (D-) and a positive ideal solution (+) by:

Formula:

$D_{i}^{+} ; i=1,2, \ldots, m$

$\left.\mathrm{D}_{\mathrm{j}}^{+}=\sqrt{\sum_{\mathrm{j}}^{\mathrm{n}}\left(\mathrm{y}_{\mathrm{if}}^{\mathrm{n}}\right.}-\mathrm{y}_{\mathrm{if}}\right)^{2}$

\section{f. Preference Value for Each Alternative}

Calculate the preference value for each alternative offered as follows:

Formula:

$\mathrm{Vi}=\frac{\mathrm{Di}}{\mathrm{D}_{\mathrm{i}}^{-}+\mathrm{D}_{\mathrm{i}}^{-}}$

Where $i=1,2,3, \ldots m$

\section{RESEARCH RESULIT AND DISCUSSION}

The results of the study are presented in the form of graphs, tables, or descriptive. Analysis and interpretation of these results is needed before being discussed.

The results of the study to determine the criteria weights are:

a. There are fatalities, missing, serious injuries and minor injuries. (C1)

b. Damage to houses and public facilities (C2)

c. Covered transportation access (C3)

d. Logistics availability (C4)
Table 3 Kecamatan Data Samples

\begin{tabular}{ll}
\hline RW Location & Criteria \\
\hline Sukajaya & A1 \\
Nanggung & A2 \\
Cigudeg & A3 \\
\hline
\end{tabular}

The research sample was only carried out in 3 districts namely Sukajaya, Nanggung and Cigudeng because the area was the worst location in the natural disaster in the early 2020 that occurred in Bogor Regency. In these locations there are still isolated local points and still need a lot of help because of closed access due to infrastructure damage.

Table 4 Normalization Decision Matrix

\begin{tabular}{lllll}
\hline Criteria & C1 & C2 & C3 & C4 \\
\hline A1 & 5 & 4 & 4 & 2 \\
A2 & 5 & 3 & 4 & 4 \\
A3 & 4 & 3 & 3 & 3 \\
\hline
\end{tabular}

The normalized decision matrix from table 4 above is intended to determine the performance ranking value of each alternative offered by using the TOPSIS method.

Table 5. Results of Weight Value Criteria

\begin{tabular}{llll}
\hline C1 & C2 & C3 & C4 \\
\hline 5 & 3 & 4 & 3 \\
\hline
\end{tabular}

Then the value of each normalized data (R) is then multiplied by the weight (W) to get the weighted normalized decision matrix. The following results are in table 6.

Table 6. Normalized values based on

\begin{tabular}{lllll}
\hline Criteria & C1 & C2 & C3 & C4 \\
\hline A1 & 5 & 4 & 4 & 2 \\
A2 & 5 & 3 & 4 & 4 \\
A3 & 4 & 3 & 3 & 3 \\
$\begin{array}{l}\text { Criteria } \\
\text { Rank Result }\end{array}$ & 66 & 34 & 41 & 29 \\
$\begin{array}{l}\text { Root of } \\
\text { Criteria }\end{array}$ & 8,12 & 5,83 & 6,40 & 5,38 \\
Rank Result & & & & \\
\hline
\end{tabular}

Where $w_{j}$ is the rank of positive value for the profit attribute (Benefit), and negative value for the cost attribute (cost)

The next step is to calculate the normalized matrix for each of the criteria offered. The following is a matrixized matrix for criteria: There are fatalities, missing, serious injuries and minor injuries. (C1) 
Table 7 Normalized Matrix C1

\begin{tabular}{llll}
\hline Criteria & C1 & Rank & Result \\
\hline A1 & 5 & 8,12 & 0,61 \\
A2 & 5 & 8,12 & 0,61 \\
A3 & 4 & 8,12 & 0,49 \\
\hline
\end{tabular}

The following is a normalized matrix for the criteria for Damage to houses and public facilities (C2).

Table 8 Normalized Matrix C2

\begin{tabular}{llll}
\hline Criteria & C2 & Rank & Result \\
\hline A1 & 4 & 5,83 & 0,68 \\
A2 & 3 & 5,83 & 0,51 \\
A3 & 3 & 5,83 & 0,52 \\
\hline
\end{tabular}

The following is a matrixized matrix for closed transportation access (C3) criteria.

Table 9 Normalized Matrix C3

\begin{tabular}{llll}
\hline Criteria & C3 & Rank & Result \\
\hline A1 & 4 & 6,40 & 0,62 \\
A2 & 4 & 6,40 & 0,62 \\
A3 & 3 & 6,40 & 0,46 \\
\hline
\end{tabular}

The following is a normalized matrix for the logistical Availability criteria (C4).

Table 10 Normalized Matrix C4

\begin{tabular}{llll}
\hline Criteria & C4 & Rank & Result \\
\hline A1 & 2 & 5,38 & 0,37 \\
A2 & 4 & 5,38 & 0,74 \\
A3 & 3 & 5,38 & 0,55 \\
\hline
\end{tabular}

The results of the performance appraisal of each criterion offered by C1, C2, C3 and C4 will be used for the final assessment in finding the best alternative to solve the problem and choosing the most ideal alternative for the decision making process.

\section{The Final Result Is Normalized Data}

The table below summarizes the values of each criterion weights calculated for the various alternatives offered. The following results are in table 11.

Table 11 Normalized Data

\begin{tabular}{lllll}
\hline Criteria & C1 & C2 & C3 & C4 \\
\hline A1 & 0,61 & 0,68 & 0,62 & 0,37 \\
A2 & 0,61 & 0,51 & 0,62 & 0,74 \\
A3 & 0,49 & 0,52 & 0,46 & 0,55 \\
\hline
\end{tabular}

\section{Normalized Matrix Is Weighted}

The next stage is to determine the weighted normalized matrix which is calculated based on the normalized data in table 11 multiplied by the results of the criteria weights in table 5 , the results are as follows.

Table 12. Weighted normalization

\begin{tabular}{lllll} 
Criteria & C1 & C2 & C3 & C4 \\
\hline A1 & 3,05 & 2,04 & 2,48 & 1,11 \\
A2 & 3,05 & 1,53 & 2,48 & 2,22 \\
A3 & 2,45 & 1,56 & 1,84 & 1,65 \\
\hline
\end{tabular}

Weighted normalized matrix shows the value of each criterion that has been calculated with the initial weighting of the alternatives offered.

\section{Value of Positive and Negative Ideal Solutions}

The value of positive and negative ideal solutions is the value of all the best values achieved from the criteria offered.

The following table

Table 13. Positive and Negative Ideal Solutions

\begin{tabular}{lllll}
\hline Criteria & C1 & C2 & C3 & C4 \\
\hline A1 & 3,05 & 2,04 & 2,48 & 1,11 \\
A2 & 3,05 & 1,53 & 2,48 & 2,22 \\
A3 & 2,45 & 1,56 & 1,84 & 1,65 \\
min & 2,45 & 1,53 & 1,84 & 1,65 \\
max & 3,05 & 2,04 & 2,48 & 2,22 \\
\hline
\end{tabular}

\section{Ideal Negative and Positive Distance Solutions}

Distance The negative and positive ideal solutions are the weighted values of each alternative to the positive and negative ideal solutions. The aim is to find out the positive and negative values. The following results are the values of $\mathrm{D}+$ and $\mathrm{D}$ - in table 14 .

Table 14. Distance of Ideal Negative \& Positive Solutions

\begin{tabular}{lll} 
Criteria & D+ & D- \\
\hline C1 & 0,60 & 0,84 \\
C2 & 0,70 & 1,03 \\
C3 & 0,40 & 0,89 \\
C4 & 1,24 & 0,78 \\
\hline
\end{tabular}

\section{Preference Value}

The final step in the TOPSIS method is to determine the Preference value. The way to calculate it is to look at the results of the values of the ideal and negative ideal solutions. The results of calculating preference values can be used as a reference in the decision making process. The best preference value taken is the highest value for each alternative weight.

Table 15 Final Preference Values 


\begin{tabular}{llr}
\hline Criteria & Score $\mathbf{V i}=(\mathbf{D i}-/(\mathbf{D i}-+\mathbf{D i}+)$ & Score $\mathbf{D}-$ \\
\hline C1 & $(0,84) /(0,84+0,60)$ & 0.58 \\
C2 & $(1.03) /(1,03+0,70)$ & 0.59 \\
$\mathbf{C 3}$ & $\mathbf{( 0 , 8 9 )} /(\mathbf{0 , 8 9 + 0 , 4 0 )}$ & $\mathbf{0 . 6 8}$ \\
C4 & $(0,78) /(0,78+1,24)$ & 0.38 \\
\hline
\end{tabular}

Based on research that has been found, the final preference value is 0.68 from C3 criteria, namely closed transportation access. Providing assistance to disaster victims in Bogor Regency is recommended to prioritize locations with closed transportation access.

\section{CONLUSIONS AND SUGGESTIONS}

\section{Conclusion}

Decision support systems using the TOPSIS method can be used to help governments and volunteers with an interest in the decision making process so that the provision of assistance to victims of natural disasters can be right on target and appropriate. The results obtained a final preference value of 0.68 from C3 criteria in order to prioritize residents with closed transportation access to channel disaster relief funds for victims of natural disasters in Bogor Regency.

\section{Suggestion}

Research can be used with a variety of other additional variables with a larger number of samples. Research can also be used to help make policy in other decision support systems.

\section{REFERENCES}

Alawiah, E. T., \& Putri, D. A. (2019). Sistem Pendukung Keputusan Pemberian Bantuan Rs. 16(1), 73-78.

Alawiah, E. T., \& Susilowati, S. (2018). Sistem Pendukung Keputusan Pembelian Vending Machine Dengan Metode TOPSIS Studi Kasus PT . KAI Commuter Jabodetabek. Jurnal Prosiding Seminar Nasional Pendidikan Teknik Informatika, 1(1), 256-261.

Nursalam, 2016, metode penelitian. (2013). 済無 No Title No Title. Journal of Chemical Information and Modeling, 53(9), 1689-1699. https://doi.org/10.1017/CB0978110741532 4.004

Parjono, Winarno, W. W., \& Luthfi, E. T. (2015). Sistem Pendukung Keputusan Menentukan Kelayakan Rekonstruksi Rumah Miskin.

Rahayu, Y. S., Farozi, M., \& Ring, J. (2015). SISTEM PENDUKUNG
REKONTRUKSI KORBAN BENCANA ALAM ( STUDI KASUS KECAMATAN PIYUNGAN KABUPATEN BANTUL ). 6-8.

Regence, A. C. P., \& Prastyowati, S. (n.d.). Sistem Penyaluran Bantuan Bencana Alam dan Keterpenuhan Kebutuhan Korban Kasus di Kabupaten Padang Pariaman.

Sugiyono. (2017). Metode Penelitian Kuantitatif, Kualitatif, dan R\&D. Alfabeta. 